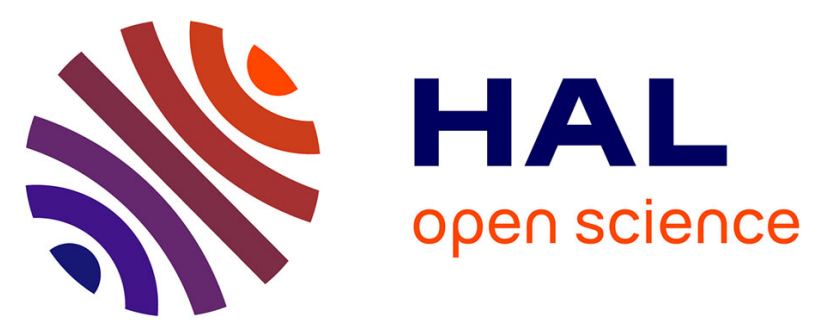

\title{
Absence of vaccinia virus detection in a remote region of the Northern Amazon forests, 2005-2015
}

Galileu Barbosa Costa, Anne Lavergne, Edith Darcissac, Vincent Lacoste, Betania Paiva Drumond, Jônatas S. Abrahão, Erna Geessien Kroon, Benoît de Thoisy, Giliane de Souza Trindade

\section{- To cite this version:}

Galileu Barbosa Costa, Anne Lavergne, Edith Darcissac, Vincent Lacoste, Betania Paiva Drumond, et al. Absence of vaccinia virus detection in a remote region of the Northern Amazon forests, 2005-2015: Absence of vaccinia virus detection in French Guiana. Archives of Virology, 2017, 162 (8), pp.2369 2373. 10.1007/s00705-017-3353-x . pasteur-01585618

\section{HAL Id: pasteur-01585618 https://hal-riip.archives-ouvertes.fr/pasteur-01585618}

Submitted on 18 Sep 2017

HAL is a multi-disciplinary open access archive for the deposit and dissemination of scientific research documents, whether they are published or not. The documents may come from teaching and research institutions in France or abroad, or from public or private research centers.
L'archive ouverte pluridisciplinaire HAL, est destinée au dépôt et à la diffusion de documents scientifiques de niveau recherche, publiés ou non, émanant des établissements d'enseignement et de recherche français ou étrangers, des laboratoires publics ou privés.

\section{(ㄷ)(i)}

Distributed under a Creative Commons Attribution| 4.0 International License 
Title: Absence of Vaccinia virus detection in a remote region from Northern Amazon forests, 2005-2015

3 Galileu Barbosa Costa ${ }^{1 \dagger}$, Anne Lavergne ${ }^{2}$, Edith Darcissac ${ }^{2}$, Vincent Lacoste ${ }^{2}$, Betânia Paiva 4 Drumond $^{1}$, Jônatas Santos Abrahão ${ }^{1}$, Erna Geessien Kroon ${ }^{1}$, Benoit de Thoisy ${ }^{2}$, Giliane de Souza $5 \quad$ Trindade ${ }^{1 \dagger}$ Universidade Federal de Minas Gerais. Av Antônio Carlos, nº 6627, Pampulha, Belo Horizonte,

$9 \quad$ Minas Gerais, Brazil. CEP: 31270-901.

2 - Laboratoire des Interactions Virus-Hôtes, Institut Pasteur de la Guyane, 23 Avenue Pasteur, BP 6010, 97306 Cayenne, French Guiana.

†Corresponding authors. E-mail address: galileuk1@gmail.com; gitrindade@ yahoo.com.br; giliane@icb.ufmg.br; Tel: +553134092747; Fax: +553134436482. Full mailing address: Avenida Presidente Antônio Carlos, 6627 - Pampulha, Belo Horizonte - MG, 31270-901

15

7

\section{Abstract}

Vaccinia virus (VACV) circulates in Brazil and other South America countries, being responsible for a zoonotic disease that usually affects dairy cattle and humans, causing economic losses and impacting animal and human health. Furthermore, VACV was already detected in wild areas from Brazilian Amazon. To better understand the natural history of VACV, we investigated its circulation in wildlife from French Guiana, a remote region in Northern Amazon forests. ELISA and plaque reduction neutralization test were performed to detect anti-Orthopoxvirus antibodies. Real-time and standard PCR targeting C11R, A56R and A26L were applied to detect VACV DNA in serum, saliva and tissue samples. VACV was not evidenced in any samples tested. These 
findings provide additional information on the VACV epidemiological puzzle. The virus could nevertheless be circulating at low levels that were not detected in areas with no human or cattle presence.

Vaccinia virus (VACV) is the prototype of the Orthopoxvirus (OPV) genus, Poxviridae family, and was used as a live vaccine around the world to eradicate smallpox. VACV circulates in zoonotic cycles involving bovine herd and dairy workers in rural areas from Brazil, causing a disease named Bovine Vaccinia (BV) which accounts for several economical losses and increasing the public health concerns [1].

In the last seventeen years, VACV spread throughout all Brazilian territory [1], though its occurrence varies among different regions. Furthermore, VACV has been detected in countries bordering Brazil, such as Argentina [2], Uruguay [3], and Colombia [4]. Although since 1999, several BV outbreaks affecting mainly dairy cattle and humans have been reported [1], natural VACV circulation had already been described in a rodent of Oryzomys genus captured in the 60's in the Amazon region [5].

During these last years in which reports of BV outbreaks have been observed, VACV circulation has been described in the Amazon region, in mammal species such as bovines, primates, coatis, and also humans [6-12]. Nevertheless, there is little information on a possible VACV sylvatic cycle and on its natural reservoirs since the origin of VACV is still unknown and its natural reservoir is still unidentified [13-16]. Given that VACV has a broad host range and that wild animals might be implicated in its transmission chain, we decided to search for VACV circulation in wildlife animals (rodents, marsupials, and bats) captured in pristine forest areas with the absence or limited anthropogenic impacts of Northern Amazon forests. 
We analyzed a total of 2,365 wild mammals from French Guiana, captured between 2005 and 2015 in tropical upland rain forest, Amazon region [17, 18]. Captured sites were located in remote forests, slightly disturbed forests (facing selective logging, hunting pressure, and low fragmentation level), secondary forests and edge between forest and open habitats (Figure 1). Wild mammals included rodents $(n=420)$, marsupials $(n=606)$ and Chiroptera $(n=1,339)$ (Table 1). All samples underwent molecular testing for VACV. To detect VACV DNA we used real-time PCR targeting the C11R and A56R genes, and semi-nested PCR targeting C11R and A26L genes [19]. A molecular approach was performed in serum and tissue samples from rodents and marsupials, and in DNA extracted from saliva and blood clots of bats. The positive controls used on molecular assays were DNA extracted from serum and liver of experimental infected Balb/c mice with Vaccinia virus Western Reserve (VACV-WR) strain and Brazilian Vaccinia (Br-VACV) group 1 and 2 viruses [20]. For those for which we were not able to have an experimental infected animal (marsupials and bats), we provided an experimentally contamination of serum and liver samples as in the protocol previously described by Dutra and co-authors [21]. Briefly, it was added different concentrations of VACV-WR and BrVACV strains (with a range from $10^{4} \mathrm{pfu} / \mu \mathrm{L}$ to $1 \mathrm{pfu} / \mu \mathrm{L}$, respectively). The experimentally contaminated samples were tested by PCR, compared to the Balb/c controls, and then used as positive controls for marsupials and bats.

In addition, serum samples from the rodents and marsupials were screened for anti-OPV IgG by ELISA and neutralizing antibodies by $\geq 50 \%$ plaque reduction neutralization test $\left(\mathrm{PRNT}_{50}\right)$ [19]. Sera were grouped into pools of 2-5 serum samples from animals belonging to the same species that were from the same collection area. No serum samples from bats were available for serological tests. For serological assays, the positive controls were also those provided by experimental infected mouse with VACV-WR and Br-VACV strains [20]. For the ELISA assay particularly, we used purified recombinant $\mathrm{A} / \mathrm{G}$ protein peroxidase conjugated as secondary antibody. We run rodent and 
marsupial samples together in the same plate (for ELISA and PRNT), comparing the results with known positive and negative rodents' serum samples.

Most of the rodents captured belong to the species Proechimys guyannensis $(46,4 \%)$, followed by Proechimys cuvieri $(11,2 \%)$ and Zygodontomys brevicauda (9,5\%). The main marsupials studied were Didelphis marsupialis (34,1\%) and Marmosa murina (26,2\%). For bat species, most of them were Desmodus rotundus (32,3\%), Carollia perspicillata $(17,2 \%)$ and Pteronotus spp. (14,0\%). All animals tested by both serological and molecular techniques were negative for VACV.

In this study, we assessed numerous forest mammal species and found no serological or molecular evidence for VACV circulation among them. Increasing efforts have been done regarding VACV ecology in South America, and some studies have highlighted the importance of wild animals and peridomestic rodents as VACV carriers [7, 22, 23, Miranda JB, personal communication/in peer review]. Our negative results contrast with the above-mentioned ones and some hypotheses can be considered in explaining the lack of evidence for VACV circulation in wild animals in French Guiana during the 2005-2015 period. One hypothesis is that wildlife was investigated in a highly preserved Northern Amazon region, where natural geographic barriers of unfavorable forest habitats exist, preventing VACV dissemination from Brazil to French Guiana. This could also be emphasized by the "dilution effect" hypothesis, taking into account that in a highly preserved environment, the maintenance of a highly diverse mammal community may prevent infection of putative more sensitive species. A great diversity of mammal species was studied, but with only a small sampling of species from which VACV has been detected in Brazil, such as Mus musculus [20], Oryzomys sp [5], and Caluromys philander [Miranda JB, personal communication/in peer review]. Furthermore, the species Didelphis albiventris from which VACV was recently detected in São Paulo State, Southeast region of Brazil [24], is not present in French 
Guiana. Nevertheless, two closely related species Didelphis imperfecta $(\mathrm{n}=2)$ and D. marsupialis ( $n=207)$ were tested.

Another explanation for the absence of VACV detection in this study could be the extremely low number of bovines in French Guiana. One hypothesis for the broad circulation of VACV in Brazil is that bovines are acting as VACV amplifiers, excreting high loads of viable particles, being a source of infection for themselves and other animals [25]. VACV can be detected in animals without clinical disease since it has been detected in blood samples and feces in animals without lesions but presenting neutralizing antibodies [25]. Due to the potential role of cattle as a viral amplifier, the presence of bovines could facilitate VACV persistence and dissemination into the environment.

VACV has recently been identified at the borders of Brazil, in countries such as Argentina [2], Uruguay [3], and Colombia [4]. Even though the circumstances of VACV detection in South American countries are still uncertain, the cattle trade and translocation has to be considered, as highlighted in Amazon region (Mato Grosso and Rondônia states) [9]. Furthermore, some authors have hypothesized that the seroprevalence of OPV-antibodies in human populations from the Amazon basin (Acre state) could be linked to agriculture and livestock practices, reinforcing the role of cattle on VACV maintenance [8].

Compared to other South American countries where VACV has been detected, a different situation is observed in French Guiana where a lower deforestation rate is observed and where only a few cattle or horses are present [26] (http://www.globalforestwatch.org/) (Figure 1). Nevertheless, our findings do not definitively establish that VACV is not circulating, and also do not exclude the possibility that small mammals can act as its reservoir in nature. However, data presented here strongly suggest the absence of circulation of VACV, or at low levels that were not detected, in remote Amazonian areas with no human impact over a long period of time. The monitoring and 
surveillance of VACV circulation is important to ensure early warning of zoonotic outbreaks for vulnerable human populations.

\section{Legend for figure:}

An overview of French Guiana with the location of the studied regions, where were implemented several trapping sites. The background of the map highlights the human footprint index expected to summarize the anthropic threats on biodiversity. These threats (accessibility, land use, human density) are summed and allowed producing an index with lower pressures strenght in light and higher pressures darker. For each studied region, the dominant habitat is given.

\section{Acknowledgements}

We thank colleagues from the Laboratoire des Interactions Virus-Hôtes, Institut Pasteur de la Guyane for their excellent technical support. We also thank Pró-Reitoria de Pesquisa from Universidade Federal de Minas Gerais (PRPq/UFMG), CAPES, FAPEMIG and CNPq. JS Abrahão, EG Kroon, and GS Trindade are researchers from CNPq.

\section{Funding}

This study was funded by two European projects, CAROLIA and RESERVOIRS, through ERDF funds and a European Commission "REGPOT-CT-2011-285837-STRonGer" grant within the FP7. This work also benefited from an "Investissements d'Avenir' grant managed by Agence Nationale de la Recherche, France (CEBA, ref. ANR-10-LABX-25-01).

\section{Conflict of interest}

Authors declare no conflict of interest. 


\section{Ethical approval}

149 Captures of rodents, bats and marsupials do not require ethic committee in French Guiana.

\section{References}

1. Kroon EG, Mota BE, Abrahão JS, da Fonseca FG, de Souza Trindade G (2011) Zoonotic Brazilian Vaccinia virus: from field to therapy. Antiviral Res 92:150-63.

2. Franco-Luiz AP, Fagundes-Pereira A, Costa GB, Alves PA, Oliveira DB, Bonjardim CA, Ferreira PC, Trindade GS, Panei CJ, Galosi CM, Abrahão JS, Kroon EG (2014) Spread of vaccinia virus to cattle herds, Argentina, 2011. Emerg Infect Dis 20:1576-8.

158 cattle serum samples from 2009, Uruguay. Emerg Infect Dis 22:2174-2177.

4. Usme-Ciro JA, Paredes A, Walteros DM, Tolosa-Pérez EN, Laiton-Donato K, del Carmen Pinzón M, Petersen BW, Gallardo-Romero NF, Li Y, Wilkins K, Davidson W, Gao J, Nishi Patel, Nakazawa Y, Reynolds MG, Satheshkumar PS, Emerson GL, Páez-Martínez A, Páez Martínez A. (2017) Detection and Molecular Characterization of Zoonotic Poxviruses Circulating in the Amazon Region of Colombia, 2014. Emerg Infect Dis. 2017 Apr [03/15/2017]. http://dx.doi.org/10.3201/eid2304.161041 
5. Fonseca FG, Lanna MCS, Campos MAS, Kitajima EW, Peres JN, Golgher RR, Ferreira PC, Kroon EG (1998) Morphological and molecular characterization of the poxvirus BeAn 58058. Arch Virol 143:1171-86.

6. Medaglia ML, Pessoa LC, Sales ER, Freitas TR, Damaso CR (2009) Spread of cantagalo virus to northern Brazil. Emerg Infect Dis 15:1142-3.

7. Abrahão JS, Silva-Fernandes AT, Lima LS, Campos RK, Guedes MI, Cota MM, Assis FL, Borges IA, Souza-Júnior MF, Lobato ZI, Bonjardim CA, Ferreira PC, Trindade GS, Kroon EG. (2010) Vaccinia virus infection in Monkeys, Brazilian Amazon. Emerg Infect Dis 16: 976-9.

8. Mota BEF, Trindade GS, Diniz TC, da Silva-Nunes M, Braga EM, Urbano-Ferreira M, Rodrigues GO, Bonjardim CA, Ferreira PC, Kroon EG (2010) Seroprevalence of orthopoxvirus in an Amazonian rural village, Acre, Brazil. Arch Virol 155:1139-1144.

9. Quixabeira-Santos JC, Medaglia MLG, Pescador CA, Damaso CR (2011) Animal Movement and Establishment of Vaccinia Virus Cantagalo Strain in Amazone Biome, Brazil. Emerg Infect Dis 17:726-9.

10. de Assis FL, Vinhote WM, Barbosa JD, de Oliveira CH, Campos KF, Silva NS, Trindade GS, Abrahão JS, Kroon EG (2013) Reemergence of Vaccinia Virus during zoonotic Outbreak, Pará State, Brazil. Emerg Infect Dis 19:2017-20. 
193

194

195

196

197

198

199

200

201

202

203

204

205

206

207

208

209

210

211

212

213

214

11. Oliveira DB, Assis FL, Ferreira PC, Bonjardim CA, de Souza Trindade G, Kroon EG, Abrahão JS (2013) Group 1 Vaccinia virus Zoonotic Outbreak in Maranhao State, Brazil. Am J Trop Med Hyg 89:1142-5.

12. Franco-Luiz AP, Fagundes-Pereira A, de Oliveira CH, Barbosa JD, Oliveira DB, Bonjardim CA, Ferreira PC, de Souza Trindade G, Abrahão JS, Kroon EG (2016b) The detection of Vaccinia virus confirms the high circulation of Orthopoxvirus in Buffaloes living in geographical isolation, Marajó Island, Brazilian Amazon. Comp Immunol Microb Infect Dis 46:16-9.

13. Trindade GS, Emerson GL, Carroll DS, Kroon EG, Damon IK (2007) Brazilian Vaccinia Viruses and Their Origins. Emerg Infect Dis 13:965-72.

14. Drumond BP, Leite JA, da Fonseca FG, Bonjardim CA, Ferreira PC, Kroon EG (2008) Brazilian Vaccinia virus strains are genetically divergent and differ from the Lister vaccine strain. Microbes Infect 10:185-97.

15. Medaglia ML, Moussatché N, Nitsche A, Dabrowski PW, Li Y, Damon IK, Lucas CG, Arruda LB, Damaso CR (2015) Genomic Analysis, Phenotype, and Virulence of the Historical Brazilian Smallpox Vaccine Strain IOC: Implications for the Origins and Evolutionary Relationships of Vaccinia Virus. J Virol 89:11909-25.

16. Trindade GS, Emerson GL, Sammons S, Frace M, Govil D, Fernandes Mota BE, Abrahão JS, de Assis FL, Olsen-Rasmussen M, Goldsmith CS, Li Y, Carroll D, Guimarães da Fonseca F, Kroon E, Damon IK (2016) Serro 2 Virus Highlights the Fundamental Genomic and Biological Features of a Natural Vaccinia Virus Infecting Humans. Viruses 8:328. 
219 17. de Thoisy B, Bourhy H, Delaval M, Pontier D, Dacheux L, Darcissac E, Donato D, Guidez A, 220 Larrous F, Lavenir R, Salmier A, Lacoste V, Lavergne A, (2016) Bioecological Drivers of Rabies 221 Virus Circulation in a Neotropical Bat Community. PLoS Neg1 Trop Dis 10:e0004378.

18. de Thoisy B, Lacoste V, Germain A, Muñoz-Jordán J, Colón C, Mauffrey JF, Delaval M,

Catzeflis F, Kazanji M, Matheus S, Dussart P, Morvan J, Setién AA, Deparis X, Lavergne A, (2009) Dengue infection in neotropical forest mammals. Vector Borne Zoonotic Dis 9:157-70.

19. Geessien Kroon E, Santos Abrahão J, de Souza Trindade G, Pereira Oliveira G, Moreira Franco

Natural Vaccinia virus infection: diagnosis, isolation, and characterization. Curr Protoc Microbiol

20. Oliveira G, Assis F, Almeida G, Albarnaz J, Lima M, Andrade AC, Calixto R, Oliveira C,

Diomedes Neto J, Trindade G, Ferreira PC, Erna G, Abrahão J (2015) From lesions to viral clones: biological and molecular diversity amongst autochthonous Brazilian vaccinia virus. Viruses 7:121837.

21. Dutra LA, de Freitas Almeida GM, Oliveira GP, Abrahão JS, Kroon EG, Trindade GS (2017)

Molecular evidence of Orthopoxvirus DNA in capybara (Hydrochoerus hydrochaeris) stool samples. Arch Virol 162:439-48.

22. Abrahão JS, Guedes MI, Trindade GS, Fonseca FG, Campos RK, Mota BF, Lobato ZI, Silva- 
243 piece in the VACV ecological puzzle: could peridomestic rodents be the link between wildlife and 244 bovine vaccinia outbreaks in Brazil? PLoS One 4:e7428.

246 23. Peres MG, Bacchiega TS, Appolinário CM, Vicente AF, Allendorf SD, Antunes JM, Moreira 247 SA, Legatti E, Fonseca CR, Pituco EM, Okuda LH, Pantoja JC, Ferreira F, Megid J (2013) 248 Serological study of vaccinia virus reservoirs in areas with and without official reports of outbreaks 249 in cattle and humans in São Paulo, Brazil. Arch Virol 158:2433-41.

251 24. Peres MG, Barros CB, Appolinário CM, Antunes JM, Mioni MS, Bacchiega TS, Allendorf SD, 252 Vincent AF, Fonseca CR, Megid J (2016) Dogs and Opossums Positive for Vaccinia virus during 253 Outbreak Affecting Cattle and Humans, São Paulo State, Brazil. Emerg Infect Dis 22:271-3.

255 25. Guedes MI, Rehfeld IS, de Oliveira TM, Assis FL, Matos AC, Abrahão JS, Kroon EG, Lobato 256 ZI, (2013) Detection of Vaccinia virus in Blood and Faeces of Experimentally Infected Cows. 257 Transbound Emerg Dis 60:552-5.

258

259 26. Hansen MC, Potapov PV, Moore R, Hancher M, Turubanova SA, Tyukavina A, Thau D, 260 Stehman SV, Goetz SJ, Loveland TR, Kommareddy A, Egorov A, Chini L, Justice CO, Townshend 261 JR (2013) High-resolution global maps of 21st-century forest cover change. Science 342:850-3. 